Charles S. Bryan, MD

\title{
Of Soap and Semmelweis
}

"Good infection control begins with good handwashing." While I preach, I wonder. Are they muttering to themselves, "How true, but how trite"? They hear, but do they listen?

The devil elbows my side. "Cut the hackneyed sentence-stay with the technical stuff." Some days, I fight him off through the inspiration of leaders in other fields-for example, Julia Child ("good cooking begins with good ingredients") or Ben Hogan ("good golf begins with a good grip"). Other days, I resist his temptation by taking refuge in the Second Great Truism: handwashing remains not only the most important infection control measure, ${ }^{1}$ but also the most neglected.

Increasing use of invasive devices makes handwashing ever more critical in our intensive care units. Albert and Condie observed handwashing after only $38 \%$ of patient contacts in two medical intensive care units. ${ }^{2}$ Physicians washed their hands less frequently than did nurses $(26 \%$ versus $40 \%, P<0.001$ ). Larson et al reported that physicians washed only about half as often compared with nurses on an oncology unit. ${ }^{3}$ Failure of physicians to observe handwashing and other infection control practices demoralizes the nurses and others. They ask: "If the

\footnotetext{
From the Department of Medicine, The University of South Carolina School of Medicine; and Richland Memorial Hospital, Columbia, South Carolina.

Address reprint requests to Charles S. Bryan, MD, ACC 2, Richland Memorial Hospital, Columbia, SC 29203.
}

doctors don't follow the guidelines, why should we?"

Let us briefly review the recent emergence of hospital infection control as a formal discipline. Until the $1960 \mathrm{~s}$, infection control was often synonymous with housekeeping policies pertaining to such now-archaic measures as routine environmental cultures and terminal fogging. Largely through the efforts of persons at the Centers for Disease Control, emphasis shifted from places and fomites to people and fingers. Infection control became, to a large extent, a nurse-centered activity. Recent confirmations that physicians wash their hands less often than do their nursing counterparts should be disquieting: have we really made much progress in the 121 years since the death of Semmelweis?

Semmelweis. Semmelweis, our martyred patron saint! How often have I, like others, recited the legend! The doctors of Vienna refused to believe his demonstration that their own hands spread lethal disease. He lost his job, went insane, and-as a final irony-died of the same infection he had labored to prevent. The legacy lingers as a grim parable of human nature. The dark side will prevail.

The revisionist interpretation of Semmelweis (most notably that of Nuland, ${ }^{4}$ previously summarized Miller ${ }^{5}$ ) offers a measure of comfort and ground for optimism. The Semmelweis legend, in retrospect, may be a figment of biographical whitewash. Parson Weems' treatment of George Washington pales by comparison. Nuland, noting that biographers had "created a mythology that compares the events of his life to those of a Greek tragedy," argues 


\section{TABLE}

\section{"WASH WISELY": SUMMARY OF CURRENT STRONGLY RECOMMENDED INDICATIONS FOR HANDWASHING'}

1. Wash before:

- Performing invasive procedures

- Caring for especially susceptible patients

2. Wash before and also after:

- Touching wounds of any type

3. Wash after:

- Situations likely to cause microbial contamination (such as contact with blood or body fluids, secretions, or excretions)

- Touching sources likely to be contaminated with epidemiologically important microorganisms (including urinemeasuring devices and secretion-collection apparatus)

- Caring for patients infected or colonized with certain epidemiologically important bacteria (eg, methicillin-resistant [beta-lactam-resistant] $S$. aureus or gentamicin-resistant $K$. pneumoniae)

\section{Wash between:}

- Contact with different patients in high-risk nursing units



Figure. The "Golden Hands Award" recognizes physicians determined by the nursing staff to be the best observers of handwashing and other infection control practices. that in the last analysis "the gods who were the professors of obstetrics did not bring it about; the hero brought it on himself."

The conflict between the young Hungarian and the Austrian professors mirrored a much larger one: an old guard versus rising Young Turks. Semmelweis enjoyed the ardent support of such emerging luminaries as Rokitansky, Skoda, and von Hebra-indeed, he became their rallying point. Yet he refused to publish even when urged to do so. He left Vienna abruptly, without even a goodbye to his friends, and at the time he still had a job offer. Organic brain disease (possibly Alzheimer's), not mental illness, necessitated his eventual confinement. And in the asylum, he probably succumbed not to streptococcal septicemia but rather to a beating (as happened not infrequently in those times).

Semmelweis lacked what educators now call "the fourth $r$ ": self-esteem. Nuland suggests that he "saw himself as a maladroit, graceless outsider, who came from the wrong place, the wrong family, the wrong social class, spoke the wrong dialect ... in short, always the outsider clanging and banging on the gates of an academic Pantheon in which he felt unworthy to dwell." 4

If the first lesson from Semmelweis' failing should be the value of self-esteem, then the second might be the value of positive as opposed to negative feedback. Physicians, like others, seldom welcome negative feedback, however well-intended. Then, as now, physicians cringed at the faintest hint of possible malpractice. Might the outcome have differed had Semmelweis only been able to formulate creative alternatives? (Co-authorship on the final draft? A collaborative prospective study? Surgeonspecific infection rates?) Quite possibly!

Two studies indicate that positive feedback improves handwashing frequency. In one, kitchen workers washed more often if given feedback based on the previous day's handwashing patterns. ${ }^{6}$ In the second, nurses given similar feedback increased handwashing compliance from $63 \%$ to $92 \% .^{7}$ There remains the obvious need to extend these techniques and findings to perhaps the most critical group: physicians.

I believe that most physicians genuinely want to do better. Larson et al made the encouraging observation that physicians' handwashing, compared to nurses', was more likely to follow dirty contact with patients and was more thorough $(P<0.001$ in both instances $) .{ }^{3}$ In the past, we may have over-stressed frequent handwashing at the expense of intelligent handwashing. "Wash wisely," rather than "wash before and after every patient contact," might be the motto of the new CDC guidelines (Table). ${ }^{1}$

Attempting to provide positive feedback to physicians at our hospital, we created a "Golden Hands Award" to recognize outstanding observers of handwashing and other infection control practices. The winners of the three annual awards-recognizing a practicing physician, a full-time teaching physician, and a house officer-are determined by nomination and vote by those who know best: the nursing staff. Although it has been suggested that Durer's familiar "Praying Hands" might represent the hands of a physician or of a surgeon, ${ }^{8}$ they might more specifically represent hands being washed (Figure). 
This beginning is, of course, terribly simplistic. There is an urgent need for creative motivational research to improve physicians' handwashing frequency. However, it may be significant to note that surgeons walked away with all three of the first year's "Golden Hands Awards." Perhaps their training, steeped in the Listerian tradition, encourages infection control measures to a greater extent than does the training of internists and others. The increasing use of invasive procedures and devices by nonsurgeons may place patients at double jeopardy. Semmelweis should properly remain the patron saint of investigative hospital epidemiology. But for applied infection control leadership, I'll take Lord Lister!

Physician epidemiologists must relate to physicians just as our nurse counterparts relate to nurses. We must not abdicate this vital leadership role. We must not only explore new ways to reduce cross contamination among high-risk patients in intensive care units, ${ }^{9}$ but we must also reinforce the tried-and-true measures on a frequent basis. Unless we do so, the devil wins-and those who enter the portals of our intensive care units might as well "abandon all hope."10

\section{REFERENCES}

1. Garner JS, Favero MS: CDC guideline for handwashing and hospital environmental control, 1985. Infect Control 1986; 7:231-243.

2. Albert RK, Condie F: Handwashing patterns in medical intensive care units. $N$ Engl J Med 1981; 304:1465-1466.

3. Larson E, McGinley KJ, Grove GL, et al: Physiologic, microbiologic, and seasonal effects of handwashing on the skin of health care personnel. $A m J$ Infect Control 1986; 14:51-59.

4. Nuland SB: The enigma of Semmelweis-An interpretation. J Hist Med Allied Sci 1979; 34:255-272.

5. Miller PJ: Semmelweis. Infect Control 1982; 3:405-409,

6. Geller ES, Eason SL, Phillips JA, et al: Interventions to improve sanitation during food preparation. Journal of Organizational Behavioral Management 1980; 2:229-240.

7. Mayer JA, Dubbert PM, Miller M, et al: Increasing handwashing in an intensive care unit. Infect Control 1986; 7:259-262.

8. Krizek TJ: The cover. JAMA 1985; 254:2861.

9. Maki DG: Skin as a source of nosocomial infection: Directions for future research. Infect Control 1986; 7:113-117.

10. Alighieri D: Lasciate ogni speranza voi ch' entrate. Inferno 1316; 3:9. 